\title{
Correction to: Effect of different PGRs on in vitro organogenesis in Viola canescens Wall. ex. Roxb. from petiole callus culture
}

\author{
Arun Kumar Khajuria $^{1,2} \cdot$ Satish Chandra' ${ }^{1}$ R. K. Manhas ${ }^{2} \cdot$ N. S. Bisht $^{1}$
}

Published online: 2 August 2021

(c) Society for Plant Research 2021

Correction to: Vegetos (2019) 32:353-362

https://doi.org/10.1007/s42535-019-00044-1

The original version of this article unfortunately contained a mistake. The abbreviation "IBA" was incorrectly resolved in the abbreviation list. "IBA" is the abbreviation for "Indole 3-butyric acid". The original article has been corrected.

Publisher's Note Springer Nature remains neutral with regard to jurisdictional claims in published maps and institutional affiliations.

The original article can be found online at https://doi.org/10.1007/ s42535-019-00044-1.

Arun Kumar Khajuria

arun.khajuria20@gmail.com

1 Plant Tissue Culture Laboratory, Department of Botany, HNB Garhwal University, Campus Pauri, Pauri Garhwal, Uttarakhand 246001, India

2 Department of Botany, Government Degree College Kathua, Kathua, Jammu and Kashmir 184104, India 